\title{
TOWARDS A DELIBERATIVE CONFLICT RESOLUTION? A REFLECTION ON STATE INCLUSIVE RESPONSE TO SUNNI-SHI'A TENSION IN INDONESIA'S DEMOCRACY
}

\author{
M. Khusna Amal \\ Institut Agama Islam Negeri (IAIN) Jember \\ iza_jbr@yahoo.com
}

\begin{abstract}
Most studies on the Sunni-Shi'a conflict concentrates on the failed peaceful resolution due to the state's discrimination against the minority religious groups in Indonesia. However, these studies overlook other spectrums of the progressive role of the state agencies in religious conflict resolution. This paper examines the state engagement in the peaceful resolution of religious conflict through an inclusive policy-making. A case study of the Sunni-Shi'a conflict 2016 in Bondowoso (East Java) showed that the local government is committed and has an inclusive policy to protect or strengthen civil rights, especially for groups that are crucial to the quality of democracy. Based on Carson and Hartz-Karp's theoretical framework, this paper shows that the local government policy has represented a model of limited deliberative conflict resolution. Although this policy was a product of public openness and willingness to hold a discussion, negotiation, and to compromise, the decision made was still exclusionary to the involvement of the Shi'a minority group.
\end{abstract}

Keywords: Sunni, Shi'a, religious conflict, local government, deliberation, and democracy. 


\section{A. Introduction}

Indonesia has witnessed a rapid surge in violence since the end of the New Order era in 1998. However, the violence largely targets minority groups within and outside the Muslim community. The 1999 clash between Muslims and Christians in various regions, such as Ambon (the capital and largest city of the Indonesian province of Maluku) and Poso (a regency of Central Sulawesi province of Indonesia), showed communal conflict in religious followers. The inter-religious conflict in the Muslim community, particularly Sunni versus Shi'a, Ahmadiyya, and other Islamic minority groups, escalated in the early 2000s (Suryana, 2017; Makin, 2017; As'ad, 2009; Mariani, 2013; Idi Warsah et al., 2019).

The growing number of religious violence towards Shi'a groups, such as what happened in Batang (Central Java) in 2000 and 2006, Bangil (East Java) 2006 and 2016, Sampang-Madura (East Java) in 2001, and Yogyakarta in 2013, (Formichi, 2014; Hilmy, 2015; Miichi, 2016; Makin, 2017), triggered significant attention and intensive debates of some Indonesia's politicians and Islam scholars. One of the interesting topics debated is the stand of the state on religious violence to minority groups. The state has failed to show a democratic stance in ensuring the freedom of belief for all citizens without discrimination. Instead of being an autonomous and neutral political institution from any influence (Weber, 1968), the state seemed powerless in dealing with intolerant forces that often discredited and persecuted the Shi'a minority groups (Bush, 2013; Akmaliah, 2015; Kovacs, 2013). 
According to scholars, the state's weakness in protecting the minority group is attributed to its inability to perform its obligation, such as ensuring security and keeping public order and maintaining autonomy in facing intolerant groups (Ali-Fauzi, 2011). For example, in the Sunni-Shi'a conflict case in Sampang, the intolerant group successfully forced the state to pass public policy that favored their religious aspiration. Due to the issuing of East Java Governor Regulation Number 55 in 2012 on Religious Activity Guidance and Deviant Sect Monitoring, the relocation of the Shi'a community in Sampang to Puspa Agro apartment (Sidoarjo), and the two-year imprisonment sentence by Sampang District Court to ustadz Tajul Muluk was strongly affected by the strong influence of conservative Islam groups (IPAC, 2016; Mustamir, 2015; Wahyudi, 2015).

The state's failure to protect minority groups is closely related to its chosen stance which tended to cooperate with intolerant groups. Such a stance was bluntly shown by Susilo Bambang Yudoyono's (SBY) presidency. In many cases, the president passed policies in favor of the conservative Islamic groups. For instance, as MUI issued a Fatwa on allegedly deviant sects in 2005, the first years of SBY's presidency, attacks on minority groups kept increasing. Contrastingly, SBY only condemned the incident and labeled it as a horizontal clash between two antagonistic community groups, rather than as an unlawful attack committed by an Islamist group on a minority (Suryana, 2017; Mietzner, 2018; Bush, 2013).

This paper analyzes the state's stance in responding to various religion-labeled sectarian conflict. It proposes that Indonesia's state in the post-New Order era did not show a 
monolithic picture compared to what happened in the previous periods. As the decentralization policy was implemented, each region showed its plural socio-political dynamics. The local governments (the representative of the state) successfully showed inclusive, clean, and good governance. In general, a government system runs based on principles of transparency, accountability, and non-discrimination (http://www.coe.int).

What happened in Bondowoso (East Java), the location of this study, confirmed the inclusive stand that the local government took in response to the Sunni-Shi'a conflict. Although the Governor Regulation (Peraturan Gubernur/ Pergub) and East Java MUI's Fatwa recommended the local government institutions to actively play their role in guiding and monitoring allegedly deviant religious sects, the Bondowoso Regency government opted to take a different path. Rather than positioning an exclusionary stand, the local government opted for inclusionary policy in dealing with religious conflict -conflicts that relate to values, claims, and identity, which involves religious issues (Ali-Fauzi, 2011). This involved Sunni mainstream Islam and the Shi'a minority group (Zainul Hamdi, 2017).

This paper conceptualizes the state as a compulsory political organization, whose administrative staffs successfully hold up the claim to the monopoly of the legitimate use of physical force in the enforcement of order (Weber, 1968). The state in this paper is not merely an autonomous political organization or immune from the influence of other social forces (Migdal, 2001). This paper demonstrates that the state consists of various parts, and the state is full of contradiction among its parts. The state's different units 
also urge negotiation, contestation, and domination among themselves, which could result in the discrepancy of the state's policies and practices. For this reason, the state is the arenas of domination and opposition (Migdal, 2001).

The state is an inclusive concept that encompasses all aspects of policy-making and the application of laws. In comparison, the government is an agent or institution that implements state policies in a political society. However, there are institutions other than the government which become part of the state, including administrative institutions of the state or bureaucracy, the military and the police, the judiciary, the governments in the regions, and parliamentary assemblies. Therefore, the government is an agent of the state, through which the state's purposes are formulated and executed (Englehart, 2007; Budiman, 1996).

This paper is based on my ethnographic research for six months in Bondowoso between 2017 and 2018. The research was useful to boost the understanding of the practice of local state officials in response to the Sunni-Shi' a conflict. More than 15 participants were interviewed, including regents, local bureaucrats, the regional people's representative council, security forces, local leaders of NU and Muhammadiyah, the Indonesian ulama council, religious harmony forums, religious leaders (kyai), and people who know the anti-Milad Fatimah mass mobilization and the process of public policies followed by local governments. Full consent for all the data in this paper, including the name of informants, was gained. Apart from these methods, secondary research was used to make sense of the practice of local state officials. Data about this practice was gained by reading and analyzing media 
reports. This research method is useful to help gain a deeper understanding of local state officials in decision-making for Sunni-Shi'a conflict resolution.

The research questions for this study focus on how the inclusionary methods implemented by the local government in managing Sunni-Shi'a conflict and the extent to which local government's inclusionary policy in managing SunniShi'a conflict represents the principles of deliberative or participatory democracy. Quoting Carson and Karp's (2001: 120-138) perspective, this paper analyzes public policies taken by local governments by considering three important aspects. These include (1) influence, where the process should have the ability to influence policy and decision making, (2) inclusion, where the process should be representative for the population and inclusive to diverse viewpoints and values, providing equal opportunity for all to participate, and (3) deliberation, where the process should provide open dialogue, access to information, respect, space to understand and reframe issues and move toward consensus.

The paper begins with a discussion of the rise of the anti-Shi'a movement in Bondowoso, followed by the local government's response to the anti-Shi'a mass mobilization in 2016. The last section focuses on public policies taken by the local government in relation to Sunni-Shi'a conflict resolution in the line of deliberative perspective.

\section{B. The Anti-Shi'a Movement}

Bondowoso, one of the regencies located in the eastern area of East Java, serves as the epicenter of Sunni-Shi'a sectarian tension. There were several tensions involved 
in these two groups during the post-New Order period. First, there was a forced dissolution of the Bondowoso IJABI Regional Administrator inauguration by a mass from conservative-radical on June 4, 2006. Another incident was the mass tension when a student of Al-Wafa Islamic Boarding School in Jambesari owned by kyai Musowir, a leader of the Shi'a group was punched on August 12, 2006. There was a mass rampage that attacked participants of Shi'a mass sermon and burned kyai Musowir's house on September 12, 2006. Fourth, another forced dissolution by a mass occurred during the IJABI anniversary and routine mass sermon event in Jambesari on December 23-24, 2006 (Syaukani, 2009).

An equally or more heated Sunni-Shi'a tension as the incidents occurred when a mass refused Milad Fatimah 2016 event, an annual rite organized by the Shi'a community. This event was organized in remembrance of the birth of sayyidah Fatimah Az-Zahra, the daughter of the Prophet Muhammad. In their refusal, the anti-Milad Fatimah groups organized a mass demonstration to protest this event. As the day for the Milad Fatimah event was getting closer (April 3), a mass marched to urge the government to not issue any permit for the Milad Fatimah event. Additionally, the anti-Milad Fatimah group also administered a counter rite in the form of a great mass sermon and collective prayer centralized at Masjid Jami' At-Taqwa (interview with habib Baqir, November 25, 2017 \& 2018).

In the resistance, the anti-Milad Fatimah groups used various issues, including the deviance and dangers of Shi'a credo for the real Islam teachings, mut'ah marriage, an insult to the Prophet's companions, and against NKRI. In many banners and posters during the rally, the writing was 'the very 
existence of Shi'a in Indonesia divide the (Islamic) followers and is an actual threat to the nation's unity'. For this reason, the mass demanded the local government not to issue the permit for organizing the Milad Fatimah event. Issuing the permit meant legitimating the Shi'a community with their deviant teachings (Interview with kyai Mudassir, November 24, 2017).

Although it was prevalent, the use of religious sectarian issues was proved effective enough to trigger cross-group Muslims' emotions to be involved in the mass rally. Framing such an issue reminds individuals of the successful 212 movements in Jakarta. Both shared the use of religious sentiment to mobilize the mass to influence the government's policy. Over a mass of 3500 people was relatively big for a regency. The antiMilad Fatimah protest was recorded as the largest Islamic rally in the history of refusal protest against Shi'a in Bondowoso. It was also in this protest that the alliance of various conservative and radical Islam groups could be realized. One of the shared elements that united them in a religious coalition was the antiShi'a sentiment (Ichwan, 2012).

The collective anti-Milad Fatimah rally involved a large mass from the various socio-religious background and an alliance between the borrowing Jeremy Menchik's term and Godly Muslims (Menchik, 2014). They comprised of conservative NU, radical FPI, Al-Irsyad Wahabi, and Salafis that defended a very conservative, literal interpretation of Islam and treat Shia Muslims with hostility, including PKS and HTI activists. Unlike the Aksi Bela Islam (Action for Defend Islam), which placed FPI as its main spokesperson, the protest to refuse Milad Fatimah in Bondowoso was initiated 
by conservative NU's elites. They gathered in a coalition called FOKUS (Forum Komunikasi Ulama Sunni or Sunni Ulama Communication Forum) (Interview with Syaeful Bahar, November 25, 2017).

The conservative NU youth also took similar initiatives and steps. They formed a movement organization called GERPAS (Gerakan Pemuda Anti-Shi'a or Anti-Shi'a Youth Movement). This organization was initiated and pioneered by a young rising kyai who graduated from Sidogiri Islamic Boarding School, specifically Kyai Mudassir. According to the Kyai, the formation of this organization was inspired by the ijtihad of national Muslim figures in forming Aliansi Nasional Anti-Shia (ANNAS) or the National Anti-Shi'a Alliance, which emerged as a response to Sampang Sunni-Shi'a conflict in 2011 (Syarif, 2017). Through GERPAS, the Kyai was actively involved in disseminating, collecting, and mobilizing Muslim Millenials to join and be involved in the Defend Aswaja rally to refuse the Milad Fatimah event (Interview with kyai Mudassir on November 24, 2017).

The two mainstream anti-Shia organizations, FOKUS and GERPAS, drove the anti-Milad Fatimah rallies. The proponents of this movement were aware that a social movement could not succeed and had a strong pressure power without support from other groups. In this context, they expanded their coalition by allying with other groups. The Muslim elites from FPI, elites from conservative Islamic boarding schools, Wahabi/Salafi groups from Al-Irsyad organization wings, PKS, and HTI activists were involved in this alliance (Interview with Matkur, November 6, 2017). 


\section{State's Inclusive Response}

The failure of peaceful conflict handling is more attributed to the absence of the state. This paper does not fully agree with the assertion that the state's presence guarantees a better conflict resolution. For instance, the state's militaristic intervention during New Order in every public issue, including in managing diversity, differences, and social turbulence, was ineffective in creating a peaceful conflict resolution. The state successfully suppressed any social turbulence, preventing it from escalating into conflict and creating social stability. However, social stability was built not based on democratic conflict management. In general, the conflict management process involved the active role of public elements and relevant stakeholders (Vitale, 2006). Therefore, such a centralistic conflict management model relying on a militaristic approach often led to artificial conflict resolution. The conflict prospects suppressed under the tight control of the military regime for years later resurfaced with violence once the New Order collapsed (Tomagola, 2003).

The state's presence with an ambivalent stand in response to a conflict was proved unable to create a peaceful conflict resolution. The stance showed by SBY's presidency in responding to the Sunni-Shi'a conflict in Sampang (East Java) and Ahmadiyah in Kuningan (West Java) could be used as a reference. A'an Suryana's research showed that at the national level, the central government in one momentum showed its enthusiasm in protecting the minority rights to embrace their own beliefs. In another momentum, the government showed an accommodative and tolerant stance to the perpetrators of violence on behalf of a religion (Suryana, 2017). 
The state's existence with its intolerance towards the minority also gave a considerable contribution to the failed peaceful conflict resolution. This assertion was proven by Ken Miichi and Yuka Kayne, Johan Wahyudi, and Hary Widyantoro's studies on the Sunni-Shi'a conflict in Sampang. In these cases, the state failed in maintaining its independence and was hijacked by the intolerant groups. The policies issued by the state tended to be discriminative to the minority group. Furthermore, the decision of the Sampang Regency Government to relocate the Shi'a group to GOR (gymnasium) Sampang and then to Puspo Agro apartment Sidoarjo (East Java) on June 20, 2013, was one form of discriminative policy. This policy was passed as the regency government's response to a fatwa from kyai or ulama in Sampang, particularly those allied in MUI (Miichi, 2016; Wahyudi, 2015; Widyantoro, 2017).

In contrast to the New Order government stances, SBY's presidency, and local government in Sampang (Madura), the Bondowoso Regency government showed commitments to strengthen an array of civil rights crucial to the quality of local democracy. In the demands of the mass that refused the Milad Fatimah 2016 event, the Regent Amin Said Husni bravely took an unpopular option by permitting the Shi'a group to continue with their religious event. The regent even ensured that the Milad Fatimah event in a public space could be held safely and free of any intimidation, threat, and persecution, particularly from the mainstream Islam group with their intolerance towards Shi'a. The regent also gave the same opportunity to the anti-Milad Fatimah groups to express their demand without forcing their wish. 
Currently, the local government has prioritized a persuasive approach in managing diversity, differences, and potential conflicts among religious communities in Bondowoso. This approach is considered to be more beneficial for the life of religious people. However, the violent approach only sacrifices the religious communities in general. This attitude was also shown by the local government in responding to the tensions and conflicts between Sunni and Shi'a groups recently. I have a different understanding of the Shi'a group, but as the leader of the regional government, I have to take regulation and laws-based policies that can benefit all citizens (Interview with Amin Said Husni, November 20, 2017).

In making either decisions or public policies as a response to Sunni-Shi'a tension, the local government did not do that centrally or in a top-down manner. Rather, they involved the relevant stakeholders including government agencies, security apparatus, and Islam civil society organizations. During the mass rally to protest the Milad Fatimah 2016, the Regent Amin Said Husni immediately coordinated and communicated with the related government bureaucracy. Intensively, the regent coordinated with Bakesbangpol (Badan Kesatuan Bangsa and Politik or National Unity and Politics Agency), security apparatus (TNI/Polri), Ministry of Religion, and other government agencies in Bondowoso Regency. In the coordination meeting, the Regent collected numerous aspirations from the state administrators for consideration to deal with the Sunni-Shi'a conflict. The chief of the National Unity and Politics Agency recommended the Regent not to worry about the threat from the mass demanding the refusal of the Milad Fatimah event. Furthermore, it was the regency government's responsibility to maintain Bondowoso's 
concord, harmony, and social stability by considering diversity and differences in belief (Interview with Abdul Manan/Chief of Bakesbangpol, October 5, 2017).

The security apparatus (TNI/Polri) proactively coordinated and communicated with the local government chief. Both institutions recommended the regent to immediately respond to the heated conflict by prioritizing the security and prevention aspects (Interview with AKBP Afrisal/Chief of Bondowoso Departmental Police, September $25,2017)$. Similar views were also stated by some members of the local House of Representatives to the regent. The insistence of the anti-Milad Fatimah group that the regent should implement the Governor Regulation (Pergub) on the monitoring and guidance of those religious sects is deemed deviant. It should not necessarily be used as the juridical basis for making policies in dealing with the SunniShi'a conflict in Bondowoso. Pergub was not based on legal regulations at a higher level. It was merely based on East Java MUI's Fatwa (No. Kep-01/SKF-MUI/JTM/I/2012), which was not a representation of the state's institution (Interview with Ahmad Fauzan, Head of Commission IV of DPRD Bondowoso, October 10, 2017).

Almost all existing elements of the government gave constructive inputs to the regent to make policies and decisions that are beneficial to the public, including the Shi'a minority. They wanted Bondowoso to be well known for its concord, peace, and tolerance in dealing with differences. Also, never wanted to mess up kebhinekaan (unity in diversity) in Bondowoso, which was built well due to incorrect policies in managing ethno-religious diversity and difference. Learning 
from the failure to deal with similar conflicts in other regions, such as the Sunni-Shi'a conflict case in Sampang (Madura) and Puger (Jember), the government was expected to prioritize peaceful method in settling the conflict in this Milad Fatimah 2016 case (Interview with Agung Tri H, Asistent I of Regent, October 21, 2017).

The Regent Amin Said Husni also coordinated and communicated with the East Java Governor at that time, Sukarwo on April 3, 2016. In his coordination, the Regent reported the Sunni-Shi'a conflict situation and condition in Bondowoso. Furthermore, the attempts made to lower the tension and to find the best way in settling the conflict were made based on the local wisdom of Bondowoso. The governor asked the regent to prevent the conflict from escalating into a clash with violence like in Sampang (Madura). The governor also facilitated the region with additional security officers from East Java Regional Police to ensure that the conflict was under control (Interview with Amin Said Husni, November $20,2017)$.

The local government did not merely coordinate and communicate vertically. They also coordinated and communicated horizontally with several social elements. MUI, FKUB, PCNU, Muhammadiyah, and figures from some Islamic boarding schools in Bondowoso included several civil society elements for opinions and discussion, dialog, and deliberations to find the solution for the Sunni-Shi'a conflict. According to some administrators of PCNU Bondowoso, the organization was in a position to give thoughts to the Regent to make the right decisions. On some occasions, PCNU also encouraged the regent to take immediate response to the Sunni-Shi'a conflict by passing inclusive and non-discriminatory policies. 
An administrator of PCNU Bondowoso said that Polres and Dandim were summoned, showing how great the regent was. The regent was condemned by the right group but succeeded in settling it culturally. The regent stated, "Shi'a is indeed different from our (Aswaja) belief/creed, yet we cannot ignore, let alone force them to leave." The then Kapolres was summoned by the regent, prevented from conducting some activities, apart from implementing the regulation (Interview with Syaeful Bahar on November 25, 2017).

A similar statement was issued by administrators of MUI Bondowoso involved in a discussion that was sponsored by the Local Government. For instance, the chairman of MUI Bondowoso, Kyai Abd. Qodir Syams, prompted the regent not to strictly follow the fatwa of MUI East Java and Governor Regulation of East Java, which recommended the local government to monitor and guide the groups deemed deviant from the real Islam teachings, such as the Shi'a minority (Interview, Sept 18, 2017).

The local government also convened a meeting and dialog with the groups directly involved in the anti-Milad Fatimah mass mobilization rally. In particular, a discussion with several religious elites associated with FOKUS -an anti-Milad Fatimah or Shi'a organization was held. Upon the discussion and negotiation, the anti-Shi'a groups were willing to lower their demand by giving space and opportunity to the Shi'a group to organize their Milad Fatimah event, provided that they did not invite their followers outside the region (Bondowoso) nor their national figures, such as Jalaluddin Rahmad as a guest or speaker. Furthermore, the anti-Milad Fatimah group from Sunni asked the government to give 
them the same chance to organize a mass sermon gathering (Interview with habib Bakir, November 25, 2017).

Based on the numerous existing regulations and results of coordination, communication, and discussion with the local government and relevant stakeholders, Regent Amin Said Husni took a relatively inclusive policy. In this policy, the regent provided both permits as well as a security guarantee for both groups involved in the conflict to organize their religious events at the same time but in a different place. For stakeholders with a pluralistic vision, the decision made by the regent has deemed the most accomodating policy which provides the greater good for all parties, particularly the Shi'a minority group. Likewise, the Shi'a group also appreciated the policy taken by the regent. A slightly different response was shown by some of the anti-Shi'a group, who thought that the policy passed by the regent was a form of local government's indecisiveness in dealing with a deviant religious sect, putting the unity of NKRI to risk (Interview with Abdul Manan, October 5, 2017).

\section{Limited Deliberative Democracy}

The local government of the Bondowoso Regency made the decision and policy to give permit and security guarantee for the Shi'a group to organize the Milad Fatimah event and for the anti-Milad Fatimah group to hold a mass sermon gathering. This could be interpreted as a representation of the government, which implemented the principles of deliberative democracy in settling a religious conflict? There are at least three parameters to be used to qualitatively assess the policy taken by the government in response to the Sunni- 
Shi'a conflict. Following Carson and Hartz-Karp's theoretical framework, inclusiveness, deliberation, and influence were the three important elements frequently used by experts in explaining a deliberative or participatory democracy.

\section{Inclusiveness}

Transparency is one of the important elements of deliberative democracy. With a transparent attitude, every person with different interests can meet, communicate, discuss, and negotiate to reach a consensus. This was shown by Bondowoso Regent in coordinating, consulting, communicating, and discussing with the relevant stakeholders, ranging from the administrative bureaucracy officials (East Java Governor, Bakesbangpol, Ministry of Religion), security apparatus (TNI/Polri), and religious organizations (MUI, FKUB, NU, Muhammadiyah, and Islamic boarding schools). However, the transparent attitude in accepting opinions from the outside was evident. Without involving them, the Regent had the authority and power to make decisions independently in settling the Sunni-Shi'a conflict. The regent was elected and fully mandated by the people through direct Regional Head Election (Pilkada). Nevertheless, the regent opted to involve some related elements, from the government and the society, in making political decisions. The regent was aware that by involving the people, the policy product would be surely far more legitimate, transparent, and accountable (Denhardt, 2007).

The regent was not only limited to the government elements. It also involved the Islam civil society 
and organization elements such as MUI, FKUB, NU, Muhammadiyah, Islamic boarding schools, and FOKUS. The willingness to be involved in a coordination meeting and discussion was motivated by the regent's efforts to find the best approach to the Sunni-Shi'a conflict solution. However, not all of these Islam organizations shared the same attitude and view in response to the Sunni-Shi'a conflict. Some of them even wished the government could take a stricter measure by refusing to issue the permit for the Milad Fatimah event (Interview with Kyai Hasan bin Abdul Muiz, December 14, 2018). Some encouraged the government to accommodate the Shi'a minority group's rights to express their religious beliefs and rites (Interview with Syaiful Bahar, November 25, 2017). Nevertheless, they all showed an open-minded attitude to attend and engage in a coordination and communication forum facilitated by the regent to find a solution to the Sunni-Shi'a conflict.

It was impossible for the processes of settling this Sunni-Shi'a conflict to run appropriately suppose each party did not put a transparent and accommodating attitude. This involved reducing the disagreement and making more attempts to find an agreement or compromise. Nevertheless, the participants involved in the decision-making processes through coordination, communication, and discussion were still limited to administrative bureaucracy elites, security apparatus, and leaders of mainstream Islam organizations. The open public did not widely participate when participation at a greater and wider scale (representative) was an 
important requirement for a deliberative public policymaking (Carson, 2005). The more the participants and the less the participation criteria limitation, the more participatory the democracy would be (Insua, 2008).

The Sunni-Shi'a conflict resolution processes were not fully transparent. All parties, particularly those directly involved in the conflict, did not participate. The counter-Milad Fatimah group joining in FOKUS was involved in the government-facilitated communication and discussion forum. Unfortunately, no representative of the Shi'a group such as IJABI, the main proponent of the Milad Fatimah event, was involved in the policymaking process through the deliberation mechanism. In this case, the chairman of IJABI Bondowoso said

\begin{abstract}
Alhamdulillah, the policies of the local government have been good. However, there is no active role in the government, especially the Department of Religion. The problems of conflict and differences in religious understanding are MORA's business. When Watimpres was here, the Department of Religion had just arrived. We have never been involved in policymaking. In general, the attitude and policies taken by the local government in conflict resolution have run well. We appreciate such accommodative policies, even though none of us are involved (Interview with habib Bakir, November 25, 2017).
\end{abstract}

The Shi'a group was fairly appreciative of the local government's stand and policy in giving permits and security for them to organize the Milad Fatimah event. The government had shown its commitment to providing services and guarantee of freedom for all society elements, particularly the Shi'a minority group in expressing their belief, an essential part of every human being (Casanova, 1992). 


\section{Deliberation}

A state's policy can be classified as deliberative as long as its policy-making process was based on deliberation, discussion, and dialog with the citizens (stakeholders). Deliberation will run well and productively when each party involved and/or invited to is given equal access to information. Therefore, it is important to develop various strategies to encourage a transparent discussion, productive debate, respect, access to information, and a room to understand and reframe the problem to reach an agreement (Ron, 2010). It was this cooperation (rather than competition) between ideas and parties with diverse interests that serve as the key to enable a meeting point or a consensus. This was a political compromise through rational public debate and negotiation rather than moral justification and normative argumentation (Pierre Jon, 2000; Deveaux, 2003; Bowen, 2003).

In a deliberative democracy, a decision is made through a deliberation mechanism. According to Habermas's perspective, this is public discursivity, not merely based on the majority vote, but the rational acceptance of all parties. In Habermas's opinion, a democratic discourse presupposes (1) open and free access for all citizens, (2) the preference transformation and objective of the participant through the debate are possible, and (3) the decision legitimacy is accepted through a rational deliberation (Insua, 2008); (Taylor, 1993). The more discursive the process (rational and transparency to public review), the more legitimate the 
product would be. No matter how coherent, systematic, and esthetic a policy or public norm is, without prior discursive test in a public space or suppose it is just established by the authority, the policy would have no legitimacy (Hardiman, 2009).

In the Sunni-Shi'a conflict resolution in Bondowoso, the local government employed a deliberation mechanism with therelevantstakeholders.Coordination, consultation, discussion, and dialog were held by the regent Amin Said Husni with the East Java Governor, TNI/Polri, Ministry of Religion, FKUB, MUI, NU, Muhammadiyah, figures from Islamic boarding schools, and anti-Milad Fatimah group. In general, both vertical (government with the governor) and horizontal (government with the society) dialogs were held formally and informally. Taking such a communicative mechanism, the local government showed its commitment to share the problems, ideas, and notions with multi-parties, aiming to achieve a public purpose that constituted universal rationality agreed upon by all people (Mardiyanta, 2011; Bowen, 1999).

In explaining the role of NU's participation, one of the NU officials stated that:

Suppose NU goes into the middle, meaning in the battle of a religious conflict, this is dangerous because there will be a justification for the people to attack them (Shi'a). NU did not enter the area of the conflict. It took a position as a conflict resolution agent. Apart from taking part in the brakes for nahdliyin people not to be involved in the conflict, $\mathrm{NU}$ also provided input to the government to make policies that were maslahah (good) for both Sunnis and Shi'ites (Interview with kyai Abd. Qodir Syams, Sept. 18, 2017). 
The deliberation mechanism initiated by the regent was done not too transparently for the public in general. The deliberation was limited to merely involving the representation of stakeholders invited to be present and engaged in the forum. Beyond those representatives, the public, could not directly access, follow, and let alone engage in the deliberation processes. The deliberation process was neither published nor broadcasted to the public through such media as radio, newspapers, local television, Facebook, or other social media. The final result of deliberation, a product of the public policymaking, was then announced by the local government together with the stakeholders in front of the public and covered by various mass media.

The reason why the policy-making process could not involve the public is that the government and relevant stakeholders were facing a situation that required a fast and appropriate response. Without an immediate definite response from the local government, the conflict would escalate and lead to violence. When the local government leaders decided through deliberation, the decision was made through a public test mechanism (Hardiman, 2009). The absence of the Shi'a group in the deliberation to issue a public policy (no matter how responsive the policy was to the Shi'a minority's rights) could be deemed as a weakness. Overall, the government policy in SunniShi' a conflict resolution had fairly strong legitimacy since it was acceptable and complied with by the majority of the Bondowoso public (Hardiman, 2009). 


\section{Influence}

Public opinion is meaningless without impact on the policy-making by the government. Even when the government involves the public in the process of making its policies through a deliberation mechanism, the policy made could not be democratic suppose it ignores these public aspirations (Deveaux, 2003). The extent of public aspirations produced through the deliberation mechanism affects the policy-making. This is one of the important things in deliberative democracy principles. The greater the influence of public capacity on the government's policy-making, the more deliberative that policy made (Hartz-Karp, 2005).

Public involvement in a set of coordinations, consultations, discussions, and communications with Regent Amin Said Husni has a significant influence on public decision or policy (Hartz-Karp, 2005). Suppose the public had no adequate capacity; it was less likely that their opinions would be considered by the regent in making such an unpopular policy. The Sunni-Shi'a conflict incident in Sampang (Madura), affirmed that the government policy was influenced or produced through a discussion mechanism with the public. Unfortunately, the dominant influence came from the intolerant public section, hence the policy made by the government was exclusionary to the Shi'a minority group's rights (Miichi, 2016).

In the conflict resolution of the Sunni-Shi'a in Bondowoso, the aspirations considered by the government were not just from certain groups. All public aspirations related to the aspirations of the two 
conflicting groups and the stakeholders were seriously considered by the government (Interview with Agung Tri H., October 21, 2017). This gave a strong impression that the public aspiration or opinion tested first through dialog, negotiation, and compromise mechanisms (based on rational argumentation, rather than moral-normative justification) had a significant influence on the SunniShi'a conflict resolution (Deveaux, 2003). The local government's decision to give a permit and protection to all groups, including the Shi'a minority, to organize their religious rite with the collectively agreed-upon provisions came from the public opinion rather than the state.

When the government's decision was based on the discussion and dialog with the public, the public involvement in the making of a decision was highly crucial. This is in line with Fraser's theory, which states that the public is in a strong position. for this reason, they could be involved in shaping opinions and making decisions. The government also played an important role in making themselves available as a public arena for shaping opinions and making decisions. Its transparency along with society's discursive involvement were the keys to democratically settling the Sunni-Shi'a conflict (Mujiburrahman, 2007). In this case, Hefner (2000; 2001) established that democratic life depended on the government and the resources and habits that grow and develop in society. 


\section{E. Conclusion}

This paper showed that the local government of Bondowoso features inclusivism in responding to the SunniShi'a conflicts. This attitude was reflected in its policies by allowing and protecting the religious gathering (pengajian) conducted by Shi'a and Sunni groups. This policy was adopted by the Regent after communicating with the East Java Governor and coordination with the State Political and Unity Body (Bakesbangpol), Security apparatus (Indonesian National Armed Force (TNI)/Indonesian National Police (Polri)), leaders of the Regional House of Representatives $(D P R D)$, and discussion with the stakeholders, including the Indonesian Ulama Council (MUI), Religious Harmony Forum (known as $F K U B$ ), NU, and Muhammadiyah. The presence of local governments with their inclusivism ensured that the resolution of religious conflicts in Bondowoso was made in the corridors of deliberative democratic principles, following Carson and Hartz-Karp's theoretical framework.

The deliberative policy model adopted by the local government of Bondowoso had some limitations. For instance, the decision-making process based on a mutual discussion was not completely open for the public on a more extensive scale to access. Furthermore, the decision-making process still could be said exclusionary to the minority voices, though the decision products were adequately inclusionary to the rights of minority Shi'a. The criteria of stakeholders from the Islamic civil society circles involved in the decision making was limited only to the mainstream Islamic organizations. Moreover, the decisions made were contemporary responses to resolve the Sunni-Shi'a conflicts. No further discussions 
to correct, examine, and revise the decision-making results to make regulations with legal force to guarantee religious freedom were made.

This paper only examined government involvement in peacefully resolving the Sunni-Shi'a conflicts in Bondowoso within a certain period. Specifically, this could be the Regent Amin Said Husni's second-term (2013-2018). Other interesting issues can be elaborated more through future researches by correlating the topics of Sunni-Shi'a conflict resolutions on minority and intolerant groups, grassroots communities, and women activists as the actual topics to develop in future studies. The dynamics of Sunni-Shi'a conflict management in Bondowoso after the regime change in 2018 can be a longitudinal and challenging topic. The new Regent will possibly continue with the existing policies. However, it can modify or make different policies issued by previous regents in managing the Sunni-Shi'a conflicts.

\section{REFERENCES}

Akmaliah, W. (2015). Kekerasan dan Pengusiran atas Nama Agama Pasca Rejim Orde Baru: Studi kasus Konflik Syiah Sampang. Ma'arif 10 (2), 222-233.

Ali-Fauzi, I. \&. (2011). Polisi, masyarakat, dan konflik keagamaan di Indonesia. Yayasan Wakaf Paramadina.

As'ad, M. (2009). Ahmadiyah and the Freedom of Religion in Indonesia. Journal of Indonesian Islam, 3 (2), 390-413.

Bowen, J. R. (1999). Legal reasoning and public discourse in Indonesian Islam." New Media in the Muslim World: The Emerging Public Sphere. Bloomington \& Indianapolis: Indiana University Press. 
Bowen, J. R. (2003). Islam, Lawa, and Equality in Indonesia: An Anthropology of Public Reasoning. Cambridge: Cambridge University Press.

Budiman, A. (1996). Teori Negara: Negara, Kekuasaan dan Ideolog. Jakarta: Gramedia.

Bush, R. (2013). Religious politics and minority rights during the Yudhoyono presidency." The Yudhoyono Presidency: Indonesia's Decade of Stability and Stagnation. Pasir Panjang Singapore: ISEAS Publishing.

Carson, L. \&.-K. (2005). Adapting and combining deliberative designs: Juries, polls, and forums." The deliberative democracy handbook: Strategies for effective civic engagement in the twenty-first century. San Francisco : Jossey-Boss, 120-138.

Casanova, J. (1992). Private and Public Religion. Social Research, 59 (1), 17-57.

Creswell, J. W. (2013). Penelitian Kualitatif dan Desain Riset. Yogyakarta: Pustaka Pelajar.

Denhardt, J. \&. (2007). The New Public Service: Serving, Not Steering . New York: M.E. Sharpe.

Deveaux, M. (2003). A Deliberative Approach to Conflicts of Culture. Political Theory, Vol. 31 (6), 780-807.

Englehart, N. A. (2007). Governments Against States: The Logic of Self- Destructive Despotism. International Political Science Review Englehart, 28 (2), 134.

Formichi, C. (2014). From Fluid Identities to Sectarian Labels, a Historical Investigation of Indonesia's Shi'i Communities . Al-Jami'ah: Journal of Islamic Studies, 52 (1), 101-126. 
Hardiman, F. B. (2009). Demokrasi Deliberatif: Menimbang Negara Hukum dan Ruang Publik dalam Teori Diskursus Jurgen Habermas. Yogyakarta: Kanisius.

Hartz-Karp, J. (2005). A Case Study in Deliberative Democracy: Diaogue with the City. Journal of Public Deliberation, 1 (1), 1-15.

Hefner, R. W. (2000). Civil Islam: Muslims and Democratization in Indonesia. Pinceton: Princeton University Press.

Hefner, R. W. (2001). Public Islam and the Problem of Democratization. Sociology of Religion. 62, 491-514.

Hilmy, M. (2015). The Political Economy Sunni-Shi'ah Conflict in Sampang Madura. Al-Jami'ah: Journal of Islamic Studies, 53 (1), , 27-51.

Ichwan, M. N. (2012). The Local Politics of Orthodoxy The Majlis Ulama Indonesia in the Post-New Order Banten. Journal of Indonesian Islam, 06 (01),, 166-194.

Insua, D. R. (2008). Towards Decision Support for Participatory Democracy. British Library Online Contents, 161-191.

IPAC. (2016). The Anti-Shi'a Movement in Indonesia. IPAC (Institute for Policy Analysis of Conflic) (p. 27). Prancis: IPAC Report.

Kovacs, A. (2013). Indonesia's Religous Conflicts: Recent Developments, Causes and Policy Implication for Peace. ASIEN 127, 48-69.

Kovacs, A. (2014). Saudi Arabia exporting Salafi education and radicalizing Indonesia's Muslims. GIGA Focus International Edition English 07, 7.

Makin, A. (2017). Homogenizing Indonesian Islam: Percution of the Shia Group in Yogyakarta. Studia Islamika, 24 (1),, 1-31. 
Mardiyanta, A. (2011). Kebijakan Publik Deliberatif: Relevansi dan Tantangan Implementasinya. Masyarakat, Kebudayaan Dan Politik 24.3, 261-271.

Mariani, N. (2013). Ahmadiyah, Conflict and Violence in Contemporary Indonesia. Indonesia Journal of Islam and Muslim Societies, 3 (1), 1-30.

Menchik, J. (2014). Productive Intolerance: Godly Nationalism in Indonesia. Comparative Studies in Society and History, 56 (3), 591-621.

Mietzner, M. B. (2018). Expalining the 2016 Islamist Mobilisation in Indonesia: Religious Intolerance, Militant Groups and the Politic of Accommodation. Asian Studies Review, 1-19.

Migdal, J. S. (2001). State in Society: Studying How States and Societies Transform and Constitute One Another. Cambridge: Cambridge University Press.

Miichi, K. Y. (2016). The Politic of Religious Pluralism in Indonesia: The Shi'a Response to the Sampang Incidents of 2011-12. TRaNS: Trans -Regional and -National Studies of Southeast Asia, 1-14.

Mujiburrahman. (2007). Indonesian Muslims in the Public Sphere: A Review of Several Studies. Journal of Indonesian Islam, 1 (02), 356-378.

Mustamir, K. (2015). Agama Menegara: Potret Pembajakan Kekuasaan Negara dan Masa Depan Syi'ah di Jawa Timur. Ma'arif, 10 (2), 268-296.

Panggabean, S. R.-F. (2010). The Patterns of Religious Conflict in Indonesia (1990-2008). Studia Islamika 17.2 , 239-298.

Pierre Jon, B. G. (2000). Governance, Politics and The State. New York: St. Martin's Press. 
Robert, W. H. (2001). Public Islam and the Problem of Democratization. Sociology of Religion. 62, 491-514.

Ron, A. (2010). The Public in Public Peace Process and in Mini Publics: A Dialogue Between Democratic Theory and Peace Studies. Peace and Conflict Studies, 17 (2), 345-377.

Suryana, A. (2017). Discrepancy in State Practices The Case of Violence against Ahmadiyah and Shi'a Minority Communities during the Presidency of Susilo Bambang Yudoyono. Al-Jami'ah, 5 (1), 71-103.

Syarif, D. I. (2017). Anti-Shi'ism in Indonesia: Geneology, Development, and Methods. Harmoni: Jurnal Multikultural \& Multireligius, 16 (1), 24-37.

Syaukani, I. (2009). Konflik Sunni-Syi'ah di Bondowoso. Harmoni Jurnal Multikultural-Multireligius, VIII (31), 85-87.

Taylor, C. (1993). Modernity and the Rise of the Public Sphere. The Tanner Lectures on Human Values. Stanford University, 14.

Tomagola, T. A. (2003). Anatomi Konflik Komunal di Indonesia: Kasus Maluku, Poso dan Kalimantan 1998-2002. In M. S. Isre, Konflik Etno-Religius Indonesia Kontemporer. Jakarta: Jakarta Puslitbang.

Vitale, D. (2006). Between deliberative and participatory democracy: A contribution on Habermas. Sage Journal, 739-766.

Wahyudi, J. (2015). Negara Sunni: Kala Negara Diambilalih Agama. Ma'arif, 10 (2), 243-268.

Warsah, I, Yusron Masduki, Imron, Mirzon Daheri, Ruly Morganna. (2019). Muslim Minority in Yogyakarta: Between Social Relationship and Religious Motivation. Qudus International Journal of Islamic Studies, 7 (2), 367-398. 
Weber, M. (1968). Economy and Society: An Outline of Interpretive Sociology. New York: Bedminster Press.

Widyantoro, H. (2017). Undemocratic Response Towards Deviant Judgments and Fatwa: Sunni-Shiite Conflict in Sampang Madura, East Java. Mazahib Jurnal Pemikiran Hukum Islam, XVI (1), 18-32.

Zainul Hamdi, A. M. (2017). Ruang Untuk Yang Kecil dan Berbeda: Pemerintahan Inklusif dan Perlindungan Minoritas. Jakarta \& Yogyakarta: Lakpesdam NU \& Gading. 